\title{
СВОЙСТВА КОМПОЗИТОВ БАКТЕРИАЛЬНОЙ ЦЕЛЛЮЛОЗЫ И НАНОЧАСТИЦ СЕРЕБРА
}

${ }^{1}$ И. Шидловский, ${ }^{1}$ А.А. Шумилова, ${ }^{1,2}$ Е.И. Шишацкая, ${ }^{1,2}$ Т. Г. Волова

${ }^{1}$ Сибирский федеральный университет, ${ }^{2}$ Институт биофизики СО РАН (ФИЦ КНЦ СО РАН),

${ }^{1}$ г. Красноярск, пр. Свободный 79, Россия; ${ }^{2}$ г. Красноярск, Академгородок 50/50, Россия

e-mail: иумилова

\section{Аннотация}

Композиты бактериальной целлюлозы (БЦ) [БЦ/AgNps], синтезированной в культуре штамма уксуснокислых бактерий Komagataeibacter xylinus VKPM B-12068 с наночастицами серебра получены гидротермальным методом при варьировании в реакционной среде концентрации $\mathrm{ArNO}_{3}$. Присутствие серебра в композитах БЦ/AgNps подтверждено элементным анализом. Показано увеличение наночастиц серебра в композите от 1,08 to 5,32 мкг/100 г при возрастании концентрации ArNO3 в среде от 0,0001 до 0,01 M. C применением РЭМ, ДСК, X-Ray, системы измерения краевых углов смачивания водой исследованы структура и свойства поверхности и физико-химические свойства композитов в зависимости от содержания серебра. С использованием диско-диффузионного метода показано, что полученные композиты обладают выраженной антибактерильной активностью по отношению к патогенной микрофлоре E.coli, Ps. eruginosa, K.pneumoniae, St.aureus,

Ключевые слова: бактериальная целлюлоза, наночастицы серебра, гидротермальный синтез, композиты, физико-химические свойства, антибактериальная активность

\section{Введение}

Бактериальная целлюлоза (БЦ) является перспективным материалом биомедицинского назначения. БЦ это биополимер, синтезируемый микроорганизмами, аналогичный по химической структуре растительной целлюлозе, обладающий уникальными свойствами, включая прочность. эластичность. газопроницаемость. высокую влагоудерживающую способность; характеризуется биосовместимостью, не проявляет цитотоксичности и не вызывает аллергических реакций (Advances in biomedical and pharmaceutical applications of functional bacterial cellulose-based nanocomposites. Hanif Ullaha, Fazli Wahid, Hélder A. Santos, Taous Khana,2016). Показано, что пленки бактериальной эффективны в качестве носителя клеток для технологий клеточной и тканевой инженерии, ранезаживляющего материала при реконструкции дефектов тканей с возможностью депонирования и доставки лекарственных препаратов [Maetal.. 2010; Saska et al.. 2011].

Собственно БЦ не обладает антибактериальной активностью, но в сочетании с хитозаном и альгинатом вызывает торможении роста патогенных микроорганизмов [Kwaketal.. 2015;Chang. Chen. 2016]. Это позволяет рассматривать композитные пленки БЦ для лечения инфицированных кожных ран. Благодаря трехмерной и пористой структуре возможно получение БЦ в композиции с металлическими частицами серебра в качестве антибактериального и ранозаживляющего средства. Металлическое серебро и его соединения обладают выраженным бактерицидным эффектом, ингибируя развитие многих патогенных микроорганизмов. Ионы ны серебра связываясь с ДНК микроорганизмов, подавляют размножение клеток, взаимодействуют с тиоловыми группами белков клеточных стенок, нарушая их структуру, транспортировку веществ в клетку, бактериальное дыхание [Bowler, Russell, 2005). Описаны различные способы получения композитов БЦ с наночастицами серебра и показана их выраженная антибактериальгная активность [Yang. 2012; Dorbe. Stoica-Guzum. 2013; Feng et al.. 2014; Wena et al.. 2015].

Цель работы - исследование физико-химических и антибактериальных свойств композитов бактериальной целлюлозы и наночастиц серебра.

\section{Материалы и методы}

Объектами исследования служили образцы пленок бактериальной целлюлозы, синтезированные в культуре уксуснокислых бактерий Komagataeibacter xylinus B-12068. Штамм выделен на кафедре биотехнологии Сибирского федерального университета из природной ассоциации Medusomyces gisevii J. Lindau (чайный гриб) селекционным путем; зарегистрирован во Всероссийской коллекции промышленных микроорганизмов (ВКПМ), коллекционный номер ВКПМ В-12068. Оптимизированная ростовая среда и условия культивирования обеспечивают высокие выходы БЦ в поверхностной статической культуре ( Прудникова, Шидловский, 2017 статья в СФУ ). Для получения очищенной БЦ пленки отделяли от культуральной жидкости, погружали в $0,5 \%$ растворе $\mathrm{NaOH}$ на 24 ч при 25-27 ${ }^{\circ} \mathrm{C}$. Далее пленки выдерживали в 0,5\% растворе соляной кислоты для нейтрализации, после чего промывали дистиллированной водой до рН 7. Высушивание пленок до постоянной массы выполняли при комнатной температуре, а также лиофилизировали с использованием лабораторной установки ALPHA 1-2/LD (Martin Christ GmbH, Германия).

Для получения композитов БЦ с наночастицами серебра использовали $\mathrm{AgNO}_{3}$ (ЗАО НПИП "Уралхиминвест", РФ) и гидротермальный метод, позволяющий без применения каких-либо химических реагентов, получать наночастицы серебра, используя БЦ в качестве восстанавливающего и стабилизирующего агента (Yang, 2012). Очищенные сырые плёнки БЦ нарезали в форме дисков диаметром 1 см, помещали в колбы с раствором AgNO3 (ЗАО НПИП "Уралхиминвест", РФ) и выдерживали течении 60 мин при $90{ }^{\circ} \mathrm{C}$; использовали три различные концентрации $\mathrm{AgNO}_{3}$ - 0,0001 M; 0.001 М и 0.01 М. Средний диаметр, размерное распределение и ширину его распределения (индекс полидисперсности (PdI)) микрочастиц измеряли с помощью анализатора частиц Zetasizer Nano ZS (Malvern, Великобритания) методом динамического рассеивания 
света. Вычисление параметров проводили с помощью программного обеспечения в соответствии с Международным Стандартом ISO 13321:1996.

Элементный состав композитов и содержание в них серебра определяли с использованием сканирующего электронного микроскопа, оснащенного системой рентгеноспектрального анализа QUANTAX 70 program??? (ТМ-3000 Hitachi, Япония).

Для изучения физико-химических свойств ПГА были использованы образцы в виде высушенных пленок и/или порошка. Термический анализ проводили с использованием дифференциально-сканирующего калориметра DSC-

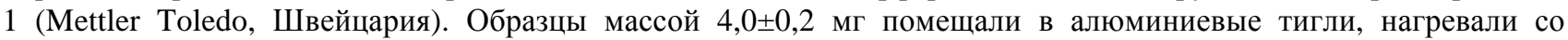
скоростью $5{ }^{\circ} \mathrm{C} /$ мин до $200{ }^{\circ} \mathrm{C}$; далее охлаждали до минус $20{ }^{\circ} \mathrm{C}$, выдерживали в течении 20 минут и повторно нагревали до $320{ }^{\circ} \mathrm{C}$. Температуру термической деградации определяли по пикам на термограммах с использованием программного обеспечения «StarE». Рентгеновские эксперименты для определения степени кристалличности (Сx) образцов выполнены на порошковом дифрактометре D8ADVANCE (Bruker AXS, Германия) с линейным детектором VANTEC. Для этого в непрерывном режиме сняты рентгенограммы с пошаговым запоминанием накопленной за 114 с интенсивностью (шаг $0,016^{\circ}$ по 2 q), режим работы прибора - 40 кВ $\times 40$ мкА, интервал сканирования от $5^{\circ}$ до $60^{\circ}$ по $2 q$. В промежутке от $48^{\circ}$ до $60^{\circ}$ наблюдался только равномерно понижающийся фон. В процессе измерений образцы вращались вокруг перпендикуляра к поверхности. Степень кристалличности определяли как величину отношения площади под рентгенограммой с вычтенным фоном к площади без вычитания аморфного фона. Для вычислений использована программа Еva из программного приложения к дифрактометру.

Микроструктуру поверхности лиофильно высушенных пленок БЦ исследовали с применением сканирующего электронного микроскопа (S5500 («Нitachi», Япония). Образцы размером $5 \times 5$ мм помещали на предметный столик и напыляли золотом с помощью установки Emitech K575X (10 мA, 2×40 секунд).

Свойства поверхности пленок БЦ изучали с помощью прибора Drop Shape Analyzer - DSA-25E («Krüss», Германия) для измерения контактных краевых углов капель воды методом Оунса-Вендта-Рабеля-Кьельбле [Owens and Wendt, 1969; Kaelble, 1970; Rabel, 1971] измерением свободной поверхностной энергии (СПЭ), ее дисперсной и полярной составляющей с последующей обработкой данных с помощью программы DSA-4.

Антибактериальный эффект композитов БЦ/AgNps тестировали в культурах референтных штаммов: Escherichia coli ATCC 25922, Pseudomonas eruginosa ATCC 27853, Klebsiella pneumoniae and Staphylococcus aureus ATCC 25923, используя общепринятый диско-диффузионный метод. В чашки Петри разливали по 20 мл агара, после его застывания на поверхность газоном производили посев теститируемых культур, используя инокулум, соответствующий по плотности 0,5 по стандарту Мак Фарланда и содержащий примерно $1.5 \times 10^{8}$ КОЕ/мл; в центр чашки помещали образец композита БЦ с наносеребром диаметром 1 мм/??? Чашки Петри помещали в термостат кверху дном и инкубируют при температуре $35^{\circ} \mathrm{C}$ в течение $18-24$ ч (в зависимости от вида тестируемого микроорганизма); после этого фотографировали. Диаметр зон ингибирования измеряли с использованием программы Image J. Program. Статистическую обработку результатов проводили с использованием стандартного пакета программы Microsoft Excel, STATISTICA 8. Оценивали средние значения и ошибки среднего в зависимости от величины выборки по U-критерию Манна-Уитни и t-критерию Стьюдента (уровни значимости: 0,05 и 0,01). Результаты приведены в виде $\mathrm{X} \pm \mathrm{m}$.

\section{Результаты}

С использованием режима гидротермального синтеза наночастиц серебра и варьирование концентрации $\mathrm{AgNO}_{3}$ в реакционном растворе получена серия композитных пленок бактериальной целлюлозы и наночастиц серебра [БЦ/AgNps], нагруженных серебром в различной степени (рис.1). Изменение концентрации АgNO в реакицонной среде в исследованных значениях $(0,0001 ; 0,001$ и 0,01 M) при стабилизации температуры среды на уровне $90{ }^{\circ} \mathrm{C}$ не влияло значительно на размеры наночастиц серебра. Средний размер частиц составил, соответственно 13; 23 и 12 нм (рис.1 Б).

$\Delta$
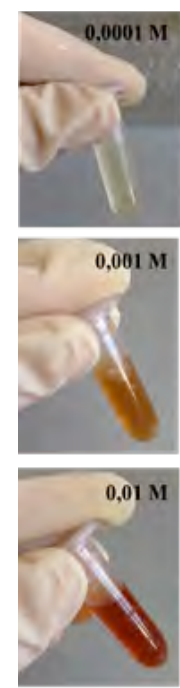
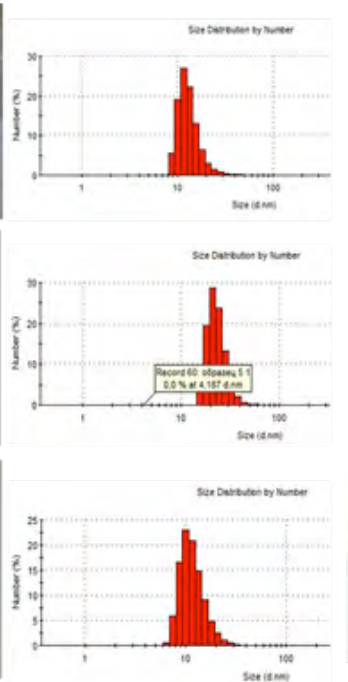

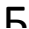
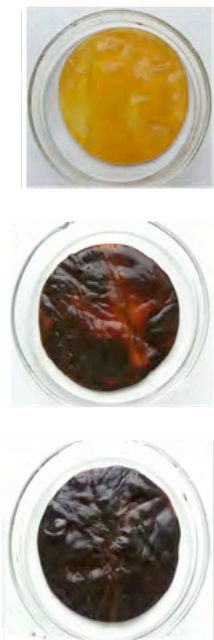
Рис.1 Вид реакционной среды при различной концентрации $\mathrm{AgNO}_{3}$ в процессе получения композитов БЦ и наночастиц серебра (А), размерное распределение наночастиц серебра (Б), фото лиофильно высушенных композитных пленок БЦ/AgNps (B)

На РЭМ снимках (рис. 2) видно, что с увеличением концентрации раствора $\mathrm{AgNO}_{3}$ в реакционной среде происходило увеличение количества наночастиц серебра, адгезированных на фибриллах БЦ и между ними. При этом показано, что способ высушивания (лиофильно или при комнатной температуре) пленок БЦ влиял на способность наночастиц $\mathrm{Ag}$ к агломерации. При высушивании пленок при комнатной температуре размер частиц Ag составил 25-60 нм, агломератов - 85-350 нм, а их количество составило до 15 на 1 мкм². На лиофильно высушенных пленках размер агломератов был больше, до 350-780 нм, а количество - до 19 на 1 мкм ${ }^{2}$.
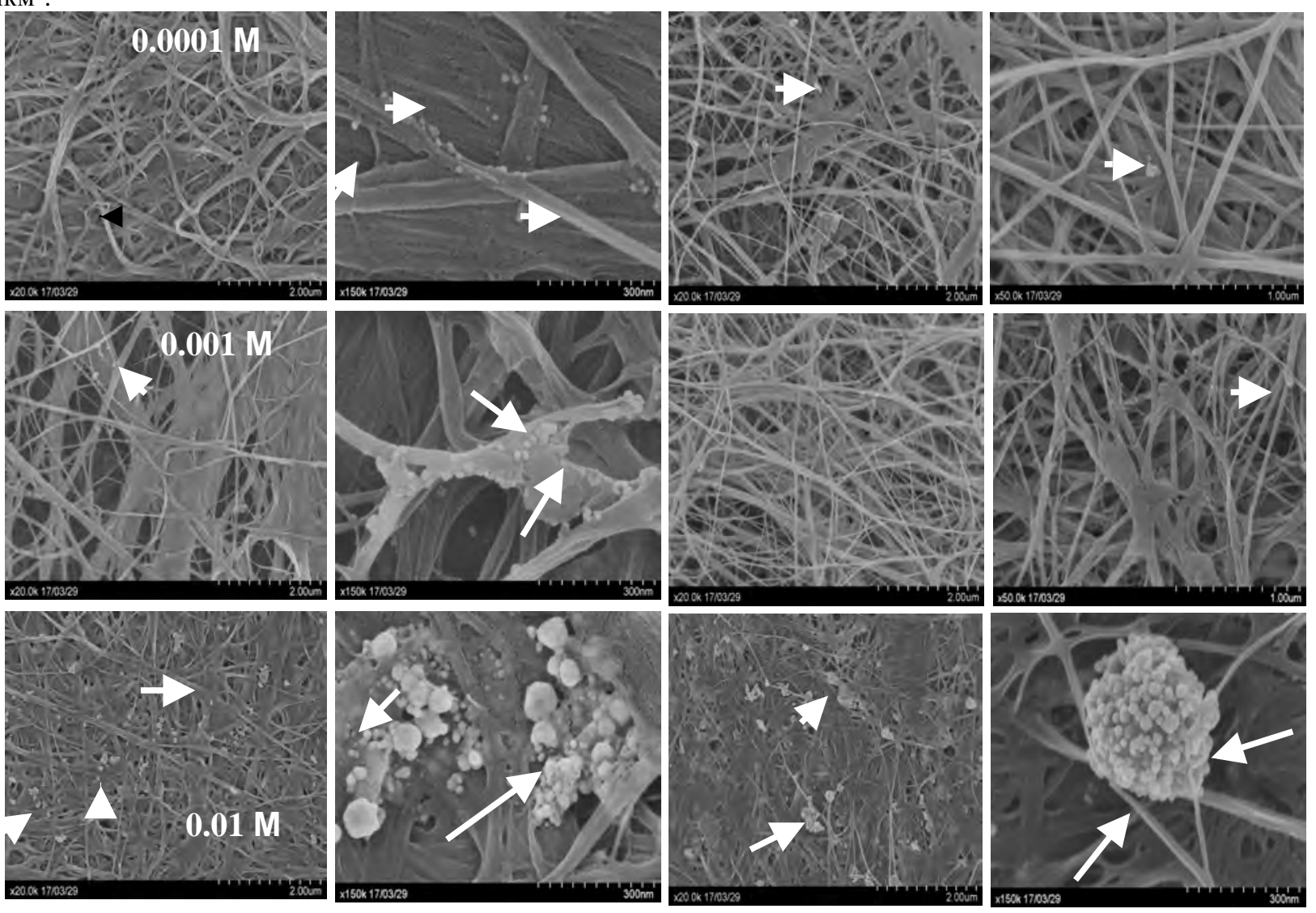

A

Б

Рис. 2. РЭМ снимки композитных пленок БЦ/AgNps, полученных при различной концентрации $\mathrm{ArNO}_{3}$ в среде, высушенных при комнатной температуре (А) и лиофильно (Б). Стрелками обозначены скопления наночастиц серебра

Количество серебра в пленках БЦ определено элементным анализом, выполненным с применением растровой электронной микроскопии, оснащенной системой рентгеноспектрального анализа (таблица 1). Среднее атомное число $\mathrm{Ag}$ в образцах с увеличением концентрации $\mathrm{AgNO}_{3}$ в среде сопровождалось закономерным увеличением его содержания в композите, - от 1,08 до 5,32 с ростом концентрации соли, соответственно, от 0,0001 до $0,01 \mathrm{M}$

Таблица 1.- Влияние концентрации ArNO3 в реакционной среде на элементный состав композитных пленок БЦ/AgNps

\begin{tabular}{|c|c|c|c|c|}
\hline \multirow{2}{*}{ Образцы } & \multicolumn{4}{|c|}{ Среднее атомное число } \\
\cline { 2 - 5 } & $\mathrm{O}$ & $\mathrm{C}$ & $\mathrm{N}$ & $\mathrm{Ag}$ \\
\hline Пленка БЦ & 59,8 & 40,1 & - & - \\
\hline $0,0001 \mathrm{M}$ & 51,03 & 43,9 & 1,48 & 1,08 \\
\hline $0,001 \mathrm{M}$ & 54,2 & 41,7 & 0,59 & 3,65 \\
\hline $0,01 \mathrm{M}$ & 50,2 & 40,7 & 1,20 & 5,32 \\
\hline
\end{tabular}

Для выявления появления возможных структурных изменений в композите привлечены рентгеноструктурный анализ и дифференциальная сканирующая калориметрия. Снижение степени 
кристалличности $\left(\mathrm{C}_{\mathrm{x}}\right)$ до 61 \% зарегистрировано для образцов композита, полученного в реакционном растворе при самой низкой концентрации $\mathrm{AgNO}_{3}$, при среднем размере наночастиц 13 нм и самом низком содержании серебра $(1,08)$ (рис. 3).

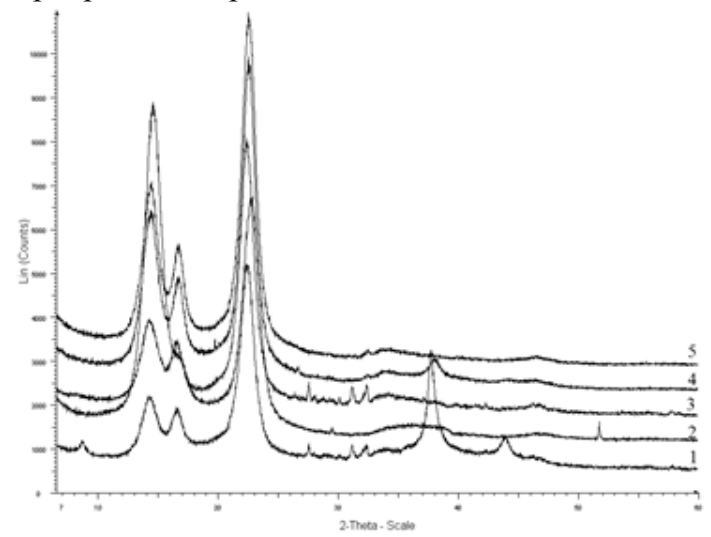

Рис. 3. Рентгенограммы композитных пленок БЦ/AgNps, полученных при различной концентрации $\mathrm{AgNO}_{3}$ в реакционном растворе: $1-0,01 \mathrm{M} ; 4-0,001 \mathrm{M} ; 5-0,0001 \mathrm{M}$, соответственно, степень кристалличности $\left(\mathrm{C}_{\mathrm{x}}\right) 61 ; 83$ и 86 \%; 2 и 3- исходная целлюлоза (без серебра), степень кристалличности 75 и 72 \%

С ростом содержания наночастиц серебра в композите до 3,65 и 5,32, степень кристалличности возрастала до 83,68 и 86,21 \% соответственно. Это выше показателя у исходных пленок БЦ, не содержащих серебра. Следует отметить вариабельность этого параметра. Ранее было зафиксировано, что на степень кристалличности БЦ значительное влияние оказывают условия биосинтеза и тип углеродного субстрата, что сказывается на $\mathrm{C}_{\mathrm{x}}$, величина которой сможет составлять от 45 до 90 \% (Прудникова, Шидловский, 2017). По литературным данным известно следующее: X-Ray лиофилизированных пленок БЦ идентифицировано три характерных пика в области $14.60^{\circ}, 16.82^{\circ}$ и $22.78^{\circ}$, соответствующие (110), (110) и (200) кристаллическим плоскостям целлюлозы (Shah et al., 2013; Shao Lio et al., 2015), это согласуется с данными рентгеноструктурного анализа настоящего исследования $\left(14.10^{\circ}, 16.50^{\circ}\right.$ и $20.5^{\circ}$ (Рис. 3 кривая 2$)$.

Результаты дифференциальной сканирующей калориметрии показали, что образцы собственно целлюлоза не имели чётко выраженных пиков в области термической деградации. Поэтому важным параметром для этого природного полимера является температура начала деструктивных процессов (Тн.дегр). Термограммы композитов представлены на рис 4.

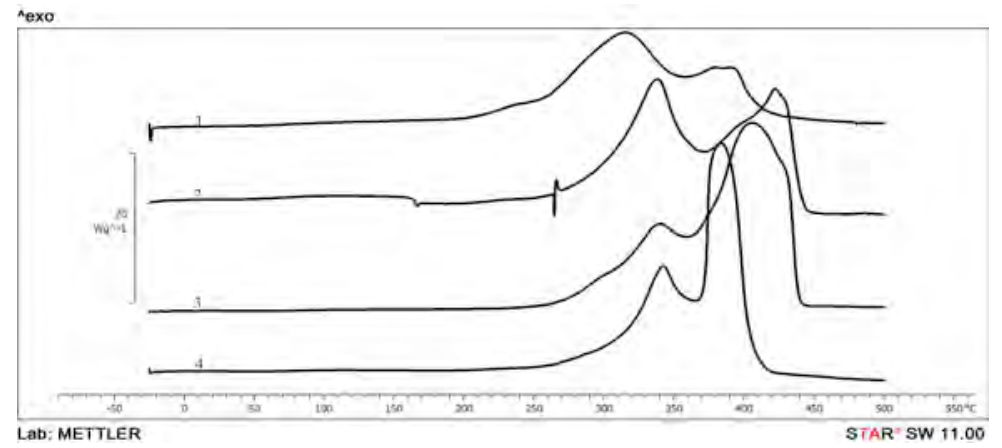

Рис. 4. Кривые ДСК: 1- исходная целлюлоза, высушенная лиофильно; 2,3 и 4 - композитные пленок БЦ/AgNps, полученные при $90{ }^{\circ} \mathrm{C}$ и различной концентрации $\mathrm{AgNO}_{3}$, соответственно, 0,01; 0,001 и 0,0001 M

У всех композитных образцов области начала термической деградации сдвинуты вправо относительно исходной БЦ; для них характерно наличие двух тиков в этой области с разрывом между пиками от 40 до $120^{\circ} \mathrm{C}$ (рис.4, кривые 2-4). В целом, наполнение пленок целлюлозы наночастицами серебра повышало термостабильность БЦ. Результаты исследования свойств поверхности композитов БЦ представлены в таблице 2. По сравнению с исходными пленками БЦ композиты с наносеребром имели более гидрофобную поверхность, косвенным показателем которой служит повышение величины краевого угла смачивания водой. Собственно пленки БЦ является достаточно гидрофильным материалом, величина краевого угла смачивания водой составляет менее $50^{\circ}$ $\left(45,5 \pm 17,6^{\circ}\right)$. У композитов БЦ/AgNps краевой угол смачивания водой увеличивался с увеличением содержания AgNps, максимально до $69 \pm 2,71^{\circ}$, при этом отмечено увеличение как дисперсной так и полярной составляющей. Подобные изменения были также описаны в работе BaoquanJia (2012), в которой краевой угол смачивания водой композитных пленок БЦ/CuNps увеличился до $110 \pm 0,4^{\circ}$, то есть в 2 раза по сравнению с исходной БЦ $\left(50,1 \pm 1,8^{\circ}\right)$.

Таблица 2. - Свойства поверхности композитов BC/AgNps 


\begin{tabular}{|c|c|c|c|}
\hline Образец & $\begin{array}{c}\text { Краевой угол } \\
\text { смачивани я водой }\left[{ }^{\circ}\right]\end{array}$ & $\begin{array}{c}\text { Дисперсная } \\
\text { составляющая } \\
{[\mathrm{mN} / \mathrm{m}]}\end{array}$ & $\begin{array}{c}\text { Полярная } \\
\text { составляющая } \\
{[\mathrm{mN} / \mathrm{m}]}\end{array}$ \\
\hline Исходная БЦ & $45,5 \pm 17,6$ & $28 \pm 9,24$ & $17,5 \pm 8,37$ \\
\hline БЦ/AgNps 0,0001M & $50,3 \pm 4,61$ & $42,6 \pm 1,01$ & $27,7 \pm 3,6$ \\
\hline БЦ/AgNps 0,001M & $68,8 \pm 1,76$ & $46,2 \pm 0,99$ & $22,6 \pm 0,77$ \\
\hline БС/AgNps 0,01M & $69 \pm 2,71$ & $44,9 \pm 1,85$ & $25,1 \pm 0,86$ \\
\hline
\end{tabular}

Для исследования антибактериальной активности полученных композитов БЦ с наночастицами серебра и антибиотиками были взяты четыре референтных штамма (три грамотрицательные: E.coli, K.pneumoniae, P.aeruginosa, и один грамположительный St.aureus), которые являются основными представителями патогенной госпитальной микрофлоры, в том числе инфецированных ран. Все образцы полученных композитов БЦ обладали бактерицидным действием по отношению к тестовым микробным культурам (таблица 3). При использовании исходной БЦ в качестве контроля зоны ингибирования микроорганизмов не наблюдали ни в одном случае, что в очередной раз свидетельствует о том, что БЦ не обладает антибактериальными свойствами.

Таблица 3 - Ингибирование патогенных бактерий на плотной среде композитами БЦ/AgNps (дискодиффузионный тест)

\begin{tabular}{|c|c|c|c|}
\hline \multirow{2}{*}{ Образцы } & \multicolumn{3}{|c|}{ Диаметр зон ингибирования (мм) } \\
\cline { 2 - 4 } & P. aeruginosa & E.coli & St.aureus \\
\hline Исходная БЦ & - & - & - \\
\hline \multicolumn{4}{|c|}{ БC/AgNps, M } \\
\hline $0,0001 \mathrm{M}$ & $12,0 \pm 0,44$ & $11,0 \pm 0,20$ & $15,2 \pm 0,73$ \\
\hline $0,001 \mathrm{M}$ & $1,13 \pm 1,15$ & $13,2 \pm 0,50$ & $14,2 \pm 0,28$ \\
\hline $0,01 \mathrm{M}$ & $14,3 \pm 2,11$ & $14,1 \pm 0,61$ & $15,1 \pm 1,58$ \\
\hline
\end{tabular}

По чувствительности к действию композитов БЦ/AgNps микроорганизмы различались между собой.

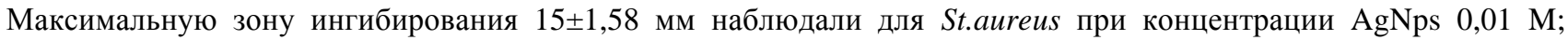
минимальную зону ингибирования (11 t0,20 мм) - для E.coli BC/AgNps 0.0001 М (таблица 3). Имеющие место различия в диаметре зон ингибирования связаны с различными реакцией и восприимчивости микроорганизмов к ионам серебра, их клеточной структурой и физиологией. Как правило, грамположительные бактерии более чувствительны к бактерицидному эффекту наночастиц Ag (Ruparelia, 2008). Аналогичные данные были получены в работе (W. Shao et al., 2015), в которой при концентрации BC-Ag 0,01M зона ингибирования роста для E.coli и St.aureus, составила $11,7 \pm 0,1$ и 11,6 $\pm 0,1$ мм соответственно. Известно, что активность наночастиц $\mathrm{Ag}$ зависит от их размера и количества в композите, при этом считается, что минимальная ингибирующая концентрация наночастиц Ag находится в диапазоне от 0,05 до 0,1 мг/мл (Castro-Mayorgaa, 2014; Bindhu, 2015). В представленной работе показано, что использование реакционного раствора с концентрацией $\mathrm{AgNO}_{3}$, равной 0,001 М, количество включенного серебра после термической обработки в БЦ пленках незначительно варьирует (3,1-3,7 у.е.), однако композиты, полученные при более высокой температуре проявляли более выраженное ингибирующее действие на микробные культуры (Прудникова, Шидловский, 2017 -СФУ). В представленной работе наибольшие зоны ингибирования наблюдали при тестировании образцов БЦ/AgNps, полученных при концентрации соли серебра в реакицонном растворе $0,01 \mathrm{M}$, и в которых фактическое содержание Аg было максимальным (5,32 у.е.), что составляет 0,024 мг/мл, это согласуется с опубликованными результатами.

\section{Заключение}

Полученные композиты пленок бактериальной целлюлозы с наночастицами серебра всесторонне исследованы, включая микроструктуру и свойства поверхности, температурные свойства и степень кристалличности, антибактериальную активность по отношению в патогенной и условно патогенной микрофолоре. Выявленные отличия структуры, физико-химических свойств свойств и характеристики поверхности влияли на степень ингибирвоания патогенной микрофлоры. Все полученные композиты обладают выраженной антибактерильной активностью по отношению к тестируемым E.coli, Ps. eruginosa, K.pneumoniae, St.aureus.

Работа выполнена при поддержке РФФИ и Правительства Красноярского края, ККФН КАК ПРАВИЛЬНО??? (грант № 16-43-242024офи) 